\title{
Technology Acceptance Model Analysis of M- Banking Using UTAUT 2 Method
}

\author{
Rr. Putri Intan Paramaeswari ${ }^{1{ }^{*}}$ Riyanarto Sarno ${ }^{2}$ \\ ${ }^{1}$ Department of Technology Management, Institut Teknologi Sepuluh Nopember, Surabaya, Indonesia \\ ${ }^{2}$ Department of Informatics, Institut Teknologi Sepuluh Nopember, Surabaya, Indonesia \\ "Corresponding author.Email: paramaeswari.19092@mhs.its.ac.id, Riyanarto@if.its.ac.id
}

\begin{abstract}
The high demand of user satisfaction becomes a benchmark to develop the technology, one of them is Mobile Banking (M-Banking). Along with the development of user needs, it is necessary to improve and develop the MBanking Technology itself so that it is expected to provide more to its users. This issue encourages the author to conducts research to discover what components could impact user interest in using M-Banking so that it can measure the level of user satisfaction. The author makes a research of M-Banking that owned by state-owned bank in Indonesia, namely BNI Mobile Banking using UTAUT2 method with the 3 addition variables: Trust, Attitude, and Satisfaction. The analysis technique was performed using SEM with WarpPLS as the software to analyse data. Results of this study are from 15 hypotheses, there are 7 hypotheses that have significant relationship, and another 8 hypotheses have insignificant relationship. In the research conducted, the implementation of BNI Mobile Banking proved to be acceptable to customers. The analysis result can be used as the recommendation and suggestion in developing the further exploration.
\end{abstract}

\section{Keywords: SEM-PLS, Trust, Attitude, Satisfaction, UTAUT2, M-Banking}

\section{INTRODUCTION}

The developments of technology today are rapidly very influential on everyday life. Lately, there are many studies which concern about use and adoption of technology [1]. In a survey conducted by Hootsuite in 2020 mentioned that, from about 272.1 million people in Indonesia, 175.4 million people or $64 \%$ among them are internet users [2]. Especially during the Covid-19 pandemic, many things become more effective and efficient using information technology. In banking industry, they have one services called Mobile Banking Technology or M-Banking which is a service that allows customers to be able to make transactions via cell phone or smartphone. Indonesia has many Banking companies that provide M-Banking services, such as BNI (Bank Negara Indonesia). The existence of MBanking owned by BNI (BNI Mobile Banking) has increasing during the pandemic. Especially according to government regulation about quarantine policies which make all the customers are directed to carry out the banking activities through BNI Mobile Banking. In 2020, BNI received an award as Top Brand Award Mobile Banking as the third place in Indonesian StateOwned Enterprises (BUMN) [3]. As one of company which is engaged in banking industry, increasing customer satisfaction becomes the main point that must be considered by the company through their products and services quality. It needs refinements and developments so that it is expected to give convenient experience to its customers. According to this issue, user acceptance analysis is needed to evaluate user acceptance and satisfaction level in using BNI MBanking.

This research aim is to analyze about what factors could impact the interest of customers in using BNI Mobile Banking. The method used is UTAUT 2 (Unified Theory of Acceptance and Use of Technology 2) by adding 3 (three) construct variables such as Trust, Attitude, and Satisfaction. SEM (Structural Equation Model) is used to draw the conclusions and PLS (Partial Least Square) is used to analyze the data [4]. The way SEM-PLS collected the data is considered as effective, efficient, and easy to understand.

The accuracy of an information becomes most important point to reach global competition success [2]. It also being an important role to know customer's perspective so that it can achieve customer satisfaction [5], [6]. That's the main reason why E-commerce being one of an important information technology that supports the growth and developments in the world.

\section{LITERATURE REVIEW}

\subsection{M-Banking}

M-Banking (Mobile Banking) is one of banking services which enable customers to access online banking activities through their cellphone or 
smartphone. In this era, M-Banking has become one of popular digital media used by society. Mane features offered to increase customers satisfaction in using Mobile Banking. This service aims to facilitate the customers to be able to do the transaction without having to come directly to their bank. M-Banking comes with various kind of features which can be directly accessed by the customer such as information services (balance and account mutation checking), bank transfer, and many other transactions [7].

Mobile Banking itself launched by Excelcom in 1995. By using technology, the banking desires to gain trust from its customers. It becomes the main motivation of the developer to develop appearance of Mobile Banking. According to this issue, various banks in the world make an innovation by launching Mobile Banking.

\subsection{BNI Mobile Banking}

BNI Mobile Banking is one of M-Banking service owned by Bank Negara Indonesia (BNI) which is one of State-Owned Enterprises (BUMN) in Indonesia. BNI Mobile Banking launched in 2014 as the main feature such as balance checking, account mutation checking, and bank transfer. BNI continuously improve their feature to facilitate the access to its customers. Nowadays, BNI Mobile Banking can be used in many other countries. This apps can be accessed both in Android and iOS [3].

\subsection{UTAUT 2}

UTAUT is one of the largest methods which can be used to measure factors that influence user to use technology. It consists of 5 independent variables (such as Performance Expectancy, Effort Expectancy, Social Influence, Facilitating Conditions), 4 dependent variables (such as Behavioral Intention and Use Behavior), and there are also 4 moderator variables such as Age, Gender, Experience, and Voluntariness of Use [8].

UTAUT 2 is the further research model of UTAUT. UTAUT 2 has same construct variables as UTAUT, but it comes with some added variable such as hedonic motivation, price value, and habit. These added factors are considered has direct and indirect affect to behavioral intention and use behavior. UTAUT 2 model is moderated by age, gender, and experience variables. Voluntariness of Use that previously existed in UTAUT had been removed. UTAUT 2 is considered can more clearly explain about behavioral intention and use behavior of the technology because UTAUT 2 inherit main structures of UTAUT with its latest improvement [1].

\subsubsection{Performance Expectancy (PE)}

Performance Expectancy is defined as a level of someone's belief that the use of technology will help them to increase their job performance. This construct influences Behavioral Intention. Performance Expectancy is related to individual belief's about how big the use of technology can help their activities, where gender and the difference of age has been shown to have an effect in technology adoption [8].

\subsubsection{Effort Expectancy (EE)}

Effort Expectancy is defined as an easiness level of the use of technology. An easy-to-use system takes less time to be understood so that it will increase user interest in using the technology. Otherwise, difficult system takes longer time for user to understand the system, so that it will decrease the user interest in using technology [8].

\subsubsection{Social Influence (SI)}

Social Influence is defined as the level which measure how far someone get the influence from people around to believe that they also have to use the technology. Social Influence describes how people can influence user interest in using technology [8].

\subsubsection{Facilitating Conditions (FC)}

Facilitating Conditions are defined as someone's belief level that the infrastructure or available facilities can support the interest of the use of technology [8].

\subsubsection{Hedonic Motivation (HM)}

Hedonic Motivation are defined as happiness level which someone gets from using the technology [1]

\subsubsection{Price Value $(P V)$}

In determining the cost and price structure has significant effect in using technology. Price Value is shown the comparison of advantages of technology according to the price required, which means that Price Value will be positive when the advantages of technology are bigger than the price that must be issued [1].

\subsubsection{Habit (HT)}

It is defined as a level where people tend to behave automatically due to a learning [1].

\subsubsection{Behavioral Intention (BI)}

Behavioral Intention is the basic theory consistency of all intention models. This variable declares the level of the intentions of an individual in using technology [1]. 


\subsubsection{Use Behavior (UB)}

Use Behavior is a variable that declares user behavior in using technology. This can be said as someone's reaction to technology acceptance which has an impact to frequency of the use of technology [1].

\subsubsection{Gender}

Gender is a variable that declares the gender of the user. It is categorized as male group and female group [1].

\subsubsection{Age}

Age is a variable that declares the age of technology users. this variable acts as a moderator variable which can measure how does the age influences the acceptance in using technology [1].

\subsubsection{Experience}

Experience is a variable that declares the level of user experience in using technology [1].

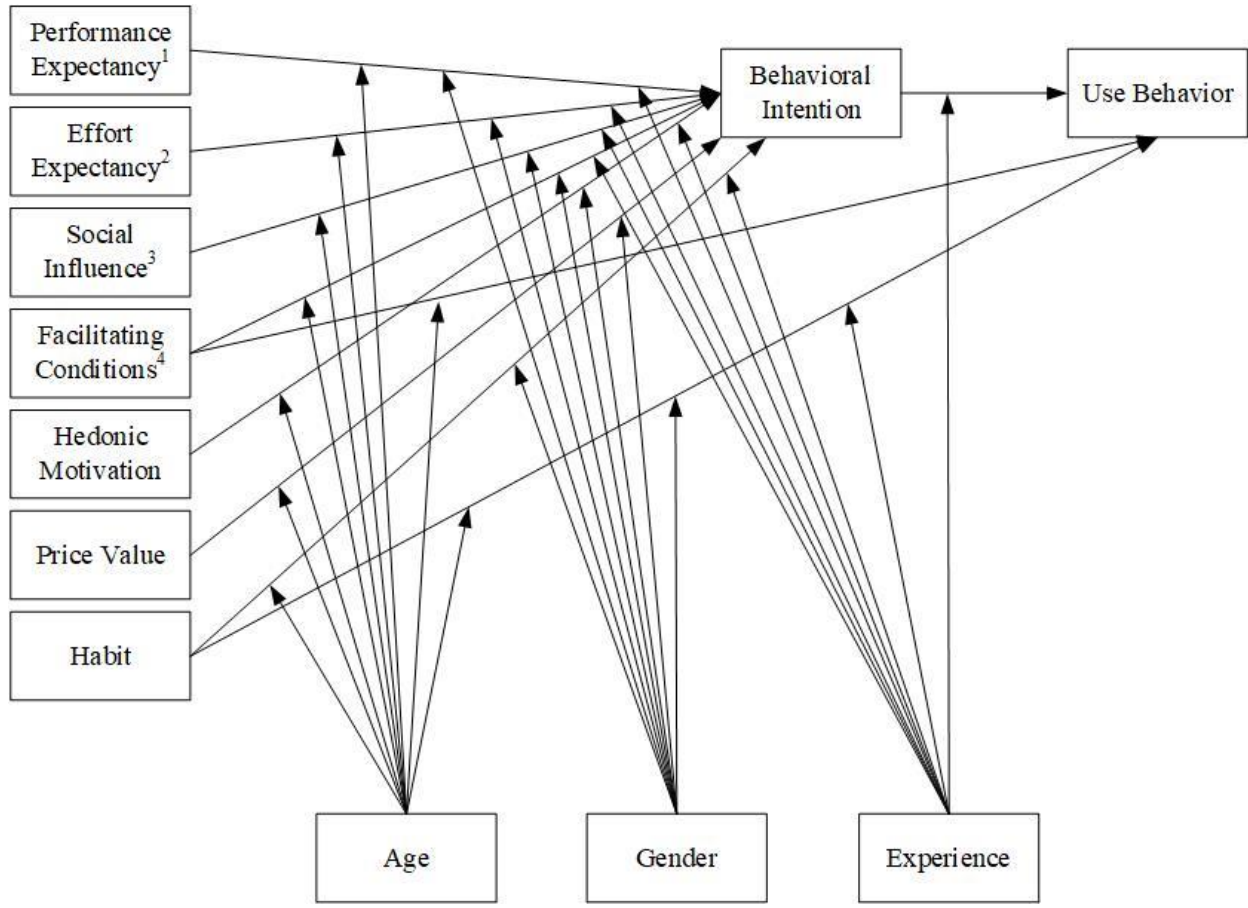

Figure 1 UTAUT 2 Construct Model [1]

\subsection{SEM}

SEM is a statistical modelling technic which consist of factor analysis, path analysis, and regression. This method is an analysis technic which basicly involve the specific version in number of other analysis method as specific cases. SEM has confirmatory characteristic, so that it can be used to determine whether a model is valid or invalid [1].

SEM has many functions, such as:

1. Supply flexible assumptions.

2. Confirmatory factor analysis which decreases an error measurement because it has many indicators in a latent variable.

3. Good graphic models which easy for user to read the output of analysis results.

4. Ability to test the models using some variables.

5. Ability to draw the models to moderator variables.
6. Ability to handle the difficult data.

\subsection{PLS}

PLS is an approach model of SEM which extensively used to analyse the quantitative data [1]. It is different from CB-SEM which aims to confirm structural relationship, PLS-SEM aims to help the researches to get the determine value from its latent variables to do the prediction [9]. Measurement model (outer model) and structural model (inner model) are the method conducted to analyse PLS-SEM. Measurement model displays relationship between the construct variables and its indicators. Structural model is a model which underlie the theory of path model. Table 1 and 2 display the criteria of measurement and structural model [10].

The first step to do the PLS-SEM is designing measurement model which use in the model. The second step is designing the structural model. After that, the authors will evaluate the results of measurement and 
structural model that has been done before. And the last step is to interpret the models according to the analysis results.

TABLE 1. Criteria of Measurement Model

\begin{tabular}{|l|l|}
\hline Evaluation Criteria & Rule of Thumb \\
\hline \multicolumn{2}{|c|}{ Reflective Measurement Model } \\
\hline Indicator Reliability & Outer Loading Indicator $>0.7$ \\
\hline $\begin{array}{l}\text { Internal Consistency } \\
\text { Reliability }\end{array}$ & $\begin{array}{l}\text { Composite Reliability and Cronbach's } \\
\text { Alpha }>0.7\end{array}$ \\
\hline Convergent Validity & Average Variance Extracted (AVE) 0.5 \\
\hline Discriminant Validity & HTMT > 0.9 \\
\hline
\end{tabular}

TABLE 2. Criteria of Structural Model

\begin{tabular}{|l|l|}
\hline $\begin{array}{l}\text { Evaluation } \\
\text { Criteria }\end{array}$ & Rule of Thumb \\
\hline $\begin{array}{l}\text { Coefficient of } \\
\text { Determinant }\left(\mathrm{R}^{2}\right)\end{array}$ & $\begin{array}{l}\text { The higher } \mathrm{R}^{2} \text { values of endogenous latent } \\
\text { variable(s) are the better. } \mathrm{R}^{2} \text { values of } 0.75 \\
\text { interpreted as substansial; 0.50 as moderate; and } \\
0.25 \text { as weak }\end{array}$ \\
\hline $\begin{array}{l}\text { Predictive } \\
\text { Relevance }\left(\mathrm{Q}^{2}\right)\end{array}$ & $\begin{array}{l}\text { Exogenous latent variable(s) will be predictive as } \\
\text { relevant to its endogenous latent variable(s) if the } \\
\mathrm{Q}^{2}>0\end{array}$ \\
\hline & $\begin{array}{l}\mathrm{F}^{2} \text { values indicates exogenous latent variable(s), } \\
\text { where } 0.02 \text { interpreted as small; } 0.15 \text { as medium; } \\
\text { End } 0.35 \text { as large effect }\end{array}$ \\
\hline
\end{tabular}

The first in performing PLS-SEM is by designing the measurement model that are proposed in the study, then designing the structural model. After that, the authors will evaluate the results of measurement and structural model that has been done before. And the last step is to interpret the models according to the analysis results.

\section{PROPOSED METHOD}

This study has steps and procedures which will be done in this research. The steps such as literature study, research planning, hypothesis determination, questionnaire design, data collection, and the last step is analysis and appraisal using SEM-PLS.
This study uses survey sampling technique as a study method. The population of this research is the customer of BNI (Bank Negara Indonesia) who are or ever using BNI Mobile Banking technology. The authors collected data using questionnaire with Google Form facilities which distributed to the samples use in this research. The alternative answers are provided using Likert Scale. After that, the data are analyzed using PLS-SEM with UTAUT 2 as the proposed method.

Proposed construct model for this study is conceived in Figure 2. There are additional variables such as TR [11], AT [12], and SATIS [13]. The hypothesis that can be tested are:

$\mathrm{H} 1=$ There is a positive and significant relationship between PE and AT

$\mathrm{H} 2$ = There is a positive and significant relationship between EE and AT

$\mathrm{H} 3$ = There is a positive and significant relationship between SI and AT

$\mathrm{H} 4=$ There is a positive and significant relationship between FC and AT

$\mathrm{H} 5=$ There is a positive and significant relationship between HM and AT

H6 = There is a positive and significant relationship between PV and AT

$\mathrm{H} 7$ = There is a positive and significant relationship between HT and AT

$\mathrm{H} 8=$ There is a positive and significant relationship between TR and AT

$\mathrm{H} 9=$ There is a positive and significant relationship between AT and BI

$\mathrm{H} 9 \mathrm{a}=$ Age moderates the relationship between AT and $\mathrm{BI}$

$\mathrm{H} 9 \mathrm{~b}=$ Gender moderates the relationship between AT and $\mathrm{BI}$

$\mathrm{H} 9 \mathrm{c}=$ Experience in using BNI Mobile Banking moderates the relationship between $\mathrm{AT}$ and $\mathrm{BI}$

$\mathrm{H} 10=$ There is a positive and significant relationship between BI and UB

$\mathrm{H} 11$ = There is a positive and significant relationship between UB and SATIS 


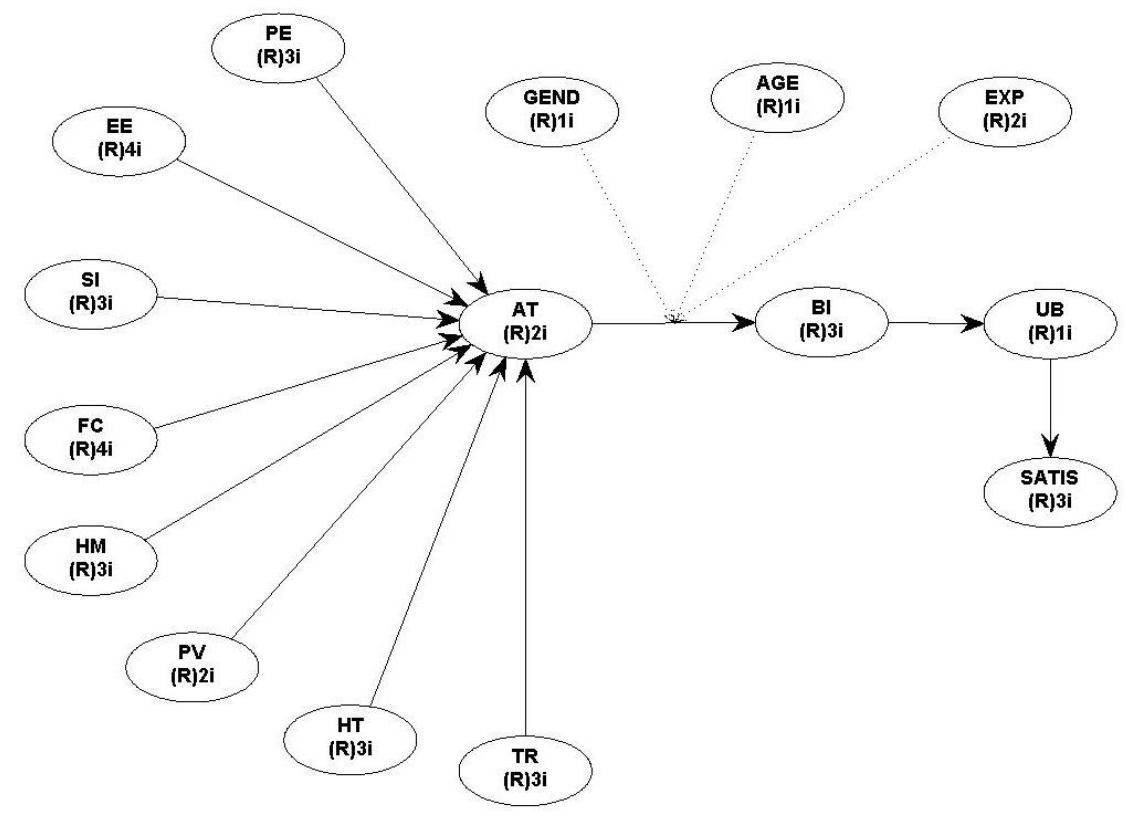

Figure 2 Construct of Proposed UTAUT 2

\section{RESULT \& ANALYSIS}

This study using PLS-SEM to do the hypotheses testing with tools WarpPLS 7.0. Measurement Model and Structural Model are represented in this chapter.

\subsection{Measurement Model (Outer Model)}

Measurement model (outer model) is a model which conduct to define how is the relationship of an indicator represents each measured latent variable or construct. The indicator will be reflective or formative, or it can be both of them. In this research, the author only uses reflective indicator.

TABLE 3. Measurement Model Results 1

\begin{tabular}{|c|c|c|}
\hline Latent Variable & Indicator & Outer Loadings \\
\hline \multirow{3}{*}{$\mathrm{PE}$} & PE1 & 0.931 \\
\hline & PE2 & 0.921 \\
\hline & PE3 & 0.856 \\
\hline \multirow{4}{*}{$\mathrm{EE}$} & EE1 & 0.922 \\
\hline & EE2 & 0.867 \\
\hline & EE3 & 0.93 \\
\hline & EE4 & 0.907 \\
\hline \multirow{3}{*}{ SI } & SI1 & 0.859 \\
\hline & $\mathrm{SI} 2$ & 0.902 \\
\hline & $\mathrm{SI} 3$ & 0.914 \\
\hline \multirow{3}{*}{$\mathrm{FC}$} & $\mathrm{FC} 1$ & 0.814 \\
\hline & $\mathrm{FC} 2$ & 0.836 \\
\hline & FC3 & 0.863 \\
\hline
\end{tabular}

\begin{tabular}{|c|c|c|}
\hline & FC4 & 0.552 \\
\hline \multirow{3}{*}{$\mathrm{HM}$} & HM1 & 0.93 \\
\hline & HM2 & 0.919 \\
\hline & HM3 & 0.873 \\
\hline \multirow{2}{*}{ PV } & PV1 & 0.924 \\
\hline & PV2 & 0.924 \\
\hline \multirow{3}{*}{ HT } & HT1 & 0.852 \\
\hline & HT2 & 0.922 \\
\hline & HT3 & 0.922 \\
\hline \multirow{3}{*}{$\mathrm{TR}$} & TR1 & 0.932 \\
\hline & TR2 & 0.923 \\
\hline & TR3 & 0.905 \\
\hline \multirow{2}{*}{ AT } & AT1 & 0.948 \\
\hline & AT2 & 0.948 \\
\hline \multirow{3}{*}{ BI } & BI1 & 0.947 \\
\hline & BI2 & 0.952 \\
\hline & $\mathrm{BI} 3$ & 0.886 \\
\hline UB & UB1 & 1 \\
\hline \multirow{3}{*}{ SATIS } & SATIS1 & 0.941 \\
\hline & SATIS2 & 0.972 \\
\hline & SATIS3 & 0.94 \\
\hline
\end{tabular}

TABLE 4. Measurement Model Results 2

\begin{tabular}{|c|c|c|c|}
\hline Latent Variable & $\begin{array}{c}\text { Composite } \\
\text { Reliability }\end{array}$ & $\begin{array}{c}\text { Cronbach's } \\
\text { Alpha }\end{array}$ & AVE \\
\hline PE & 0,065 & 0,616 & 0,567 \\
\hline EE & 0,659 & 0,644 & 0,572 \\
\hline SI & 0,640 & 0,605 & 0,553 \\
\hline
\end{tabular}




\begin{tabular}{|c|c|c|c|}
\hline FC & 0,594 & 0,053 & 0,419 \\
\hline HM & 0,648 & 0,620 & 0,572 \\
\hline PV & 0,640 & 0,576 & 0,593 \\
\hline HT & 0,644 & 0,612 & 0,562 \\
\hline TR & 0,655 & 0,631 & 0,588 \\
\hline AT & 0,657 & 0,616 & 0,624 \\
\hline BI & 0,066 & 0,064 & 0,599 \\
\hline UB & 1,000 & 1,000 & 1,000 \\
\hline SATIS & 0,671 & 0,658 & 0,628 \\
\hline
\end{tabular}

Table 3 and 4 display the results of measurement model. According to the results, It is indicated whether all indicators are valid, but since $\mathrm{FC} 4$, one of the indicators of the facilitating conditions variable, has an outer loading of 0.552 which is lower than 0.7 , it is necessary to delete the low reliability indicator and rebuild the model until all the test results becomes reliable.

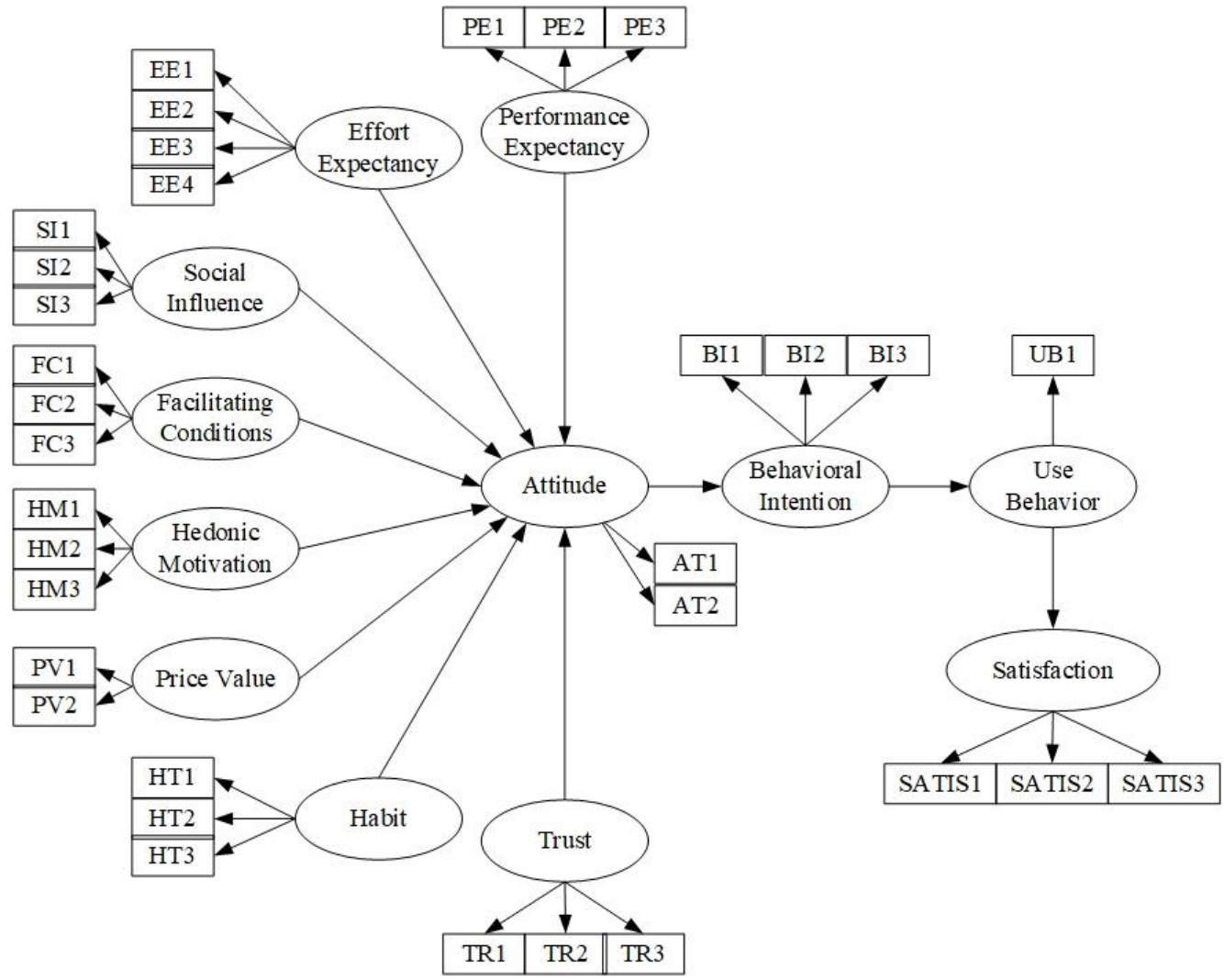

Figure 3 New SEM Construction of BNI Mobile Banking

Figure 3 shows new SEM construction model of BNI Mobile Banking which consists of PE, EE, SI, FC, HM, PV, HT, TR, AT, BI, UB, and SATIS.

\subsection{Structural Model (Inner Model)}

Structural model is concept model of path model. Structural model results bring through the author to decide whether the empirical data supports theory/concept, so that they can decide whether the theory/concept has been confirmed empirically or not.

Table 5. R-Squared and Q-Squared Result

\begin{tabular}{|c|c|c|}
\hline Latent Variable & $\mathbf{R}^{\mathbf{2}}$ & $\mathbf{Q}^{\mathbf{2}}$ \\
\hline $\mathrm{AT}$ & 0.772 & 0.773 \\
\hline $\mathrm{BI}$ & 0.630 & 0.632 \\
\hline
\end{tabular}

\begin{tabular}{|c|c|c|}
\hline UB & 0.480 & 0.486 \\
\hline SATIS & 0.457 & 0.461 \\
\hline
\end{tabular}

Table 5 shows the result of Coefficient of Determinant $\left(\mathrm{R}^{2}\right)$ and Predictive Relevance $\left(\mathrm{Q}^{2}\right)$. AT variable has $R^{2}$ value as 0.772 which means exogenous variables in the research affect simultaneously to AT variable as $77.2 \%$, and another $22.8 \%$ has affected from another variables, it represents as substantial model. BI has $\mathrm{R}^{2}$ value as 0.630 which means exogenous variables in the research affect simultaneously to BI variable as $63 \%$, and another $37 \%$ has affected from another variables, it represents as substantial model. UB variable has $\mathrm{R}^{2}$ value as 0.480 which means exogenous variables in the research affect simultaneously to UB variable as $48 \%$, and another $52 \%$ has affected from another variables, it represents as moderate model. Satisfaction 
has $\mathrm{R}^{2}$ value as 0.457 which means exogenous variables in the research affect simultaneously to SATIS variable as $45.7 \%$, and another $54.3 \%$ has affected from another variables, it represents as weak model.

Table 6. Path Coefficient and P-Value Result

\begin{tabular}{|c|c|c|}
\hline Variable & Path Coefficient & P-Value \\
\hline $\mathrm{PE} \rightarrow \mathrm{AT}$ & 0.199 & 0.008 \\
\hline $\mathrm{EE} \rightarrow \mathrm{AT}$ & 0.115 & 0.131 \\
\hline $\mathrm{SI} \rightarrow \mathrm{AT}$ & 0.109 & 0.069 \\
\hline $\mathrm{FC} \rightarrow \mathrm{AT}$ & 0.021 & 0.396 \\
\hline $\mathrm{HM} \rightarrow \mathrm{AT}$ & 0.332 & 0.007 \\
\hline $\mathrm{PV} \rightarrow \mathrm{AT}$ & 0.080 & 0.183 \\
\hline $\mathrm{HT} \rightarrow \mathrm{AT}$ & 0.245 & 0.004 \\
\hline $\mathrm{TR} \rightarrow \mathrm{AT}$ & 0.241 & 0.005 \\
\hline $\mathrm{AT} \rightarrow \mathrm{BI}$ & 0.761 & $<0.001$ \\
\hline $\mathrm{BI} \rightarrow \mathrm{UB}$ & 0.693 & $<0.001$ \\
\hline $\mathrm{UB} \rightarrow \mathrm{SATIS}$ & 0.676 & $<0.001$ \\
\hline
\end{tabular}

In structural model, to conclude whether the estimation predictive among its latent variables is positive or negative through path coefficient, and significant or not significant through p-values. According to table 5, it shows that PE, HM, HT, and TR have positive effect and significant to AT. AT to BI, BI to UB, and UB to SATIS also have positive effect and significant in each relation. For EE, SI, FC, and PV has positive effect but not significant to AT.

\subsection{Hypothesis Testing}

The hypothesis compared between its t-value and ttable to find out whether it's accepted or not. In this research, authors use significance level as $5 \%$ with confidence degree as $95 \%$. The critical value of it generates number \pm 1.96 . It means that if $\mathrm{t}$-value $>\mathrm{t}$ table (more than 1.96 or less than -1.96), the hypothesis will be accepted (H0 rejected and Ha accepted).

Table 7. Hypothesis Result of BNI Mobile Banking

\begin{tabular}{|c|c|c|c|}
\hline Hypothesis & Variable & T-Value & Notes \\
\hline $\mathrm{H} 1$ & $\mathrm{PE} \rightarrow \mathrm{AT}$ & 2.455 & Accepted \\
\hline $\mathrm{H} 2$ & $\mathrm{EE} \rightarrow \mathrm{AT}$ & 1.129 & Not Accepted \\
\hline $\mathrm{H} 3$ & $\mathrm{SI} \rightarrow \mathrm{AT}$ & 1.494 & Not Accepted \\
\hline $\mathrm{H} 4$ & $\mathrm{FC} \rightarrow \mathrm{AT}$ & 0.264 & Not Accepted \\
\hline $\mathrm{H} 5$ & $\mathrm{HM} \rightarrow \mathrm{AT}$ & 2.472 & Accepted \\
\hline $\mathrm{H} 6$ & $\mathrm{PV} \rightarrow \mathrm{AT}$ & 0.908 & Not Accepted \\
\hline $\mathrm{H} 7$ & $\mathrm{HT} \rightarrow \mathrm{AT}$ & 2.677 & Accepted \\
\hline
\end{tabular}

\begin{tabular}{|c|c|c|c|}
\hline H8 & TR $\rightarrow$ AT & 2.599 & Accepted \\
\hline H9 & AT $\rightarrow$ BI & 19.699 & Accepted \\
\hline H9a & GEND*AT $\rightarrow$ BI & 0.187 & Not Accepted \\
\hline H9b & AGE*AT $\rightarrow$ BI & 1.333 & Not Accepted \\
\hline H9c & EXP*AT $\rightarrow$ BI & 0.102 & Not Accepted \\
\hline H10 & BI $\rightarrow$ UB & 9.994 & Accepted \\
\hline H11 & UB $\rightarrow$ SATIS & 10.576 & Accepted \\
\hline
\end{tabular}

As we can see in Table 6, it shows the hypothesis result of this research. It shows that $\mathrm{H} 1, \mathrm{H} 5, \mathrm{H} 7, \mathrm{H} 8$, and $\mathrm{H} 9$ are accepted, it means that PE, HM, HT, and TR affect AT. H10 is accepted, which means that BI affect $\mathrm{UB}$, and $\mathrm{H} 11$ is also accepted which means that UB affect SATIS.

According to table 6, there are some hypotheses that are not accepted too, such as H2, H3, H4, H6, H9a, $\mathrm{H} 9 \mathrm{~b}$, and $\mathrm{H} 9 \mathrm{c} . \mathrm{H} 2, \mathrm{H} 3, \mathrm{H} 4$, and $\mathrm{H} 6$ which indicate the relation between $\mathrm{EE}, \mathrm{SI}, \mathrm{FC}$, and $\mathrm{PV}$ to $\mathrm{AT}$ are not accepted, it means that EE, SI, FC, and PV have not an impact to AT. In H9a, H9b, and H9c, it indicates that Gender, Age and Experience do not moderate AT to BI.

\section{CONCLUSION}

This study is based on 127 respondents of Bank Negara Indonesia (BNI) customers who use the BNI Mobile Banking. Data was collected using Google Form digital questionnaire facility. Based on Confirmatory Factor Analysis (CFA) that has been carried out, from 33 indicators, there is 1 (one) indicator/ questionnaire item that is not valid, namely the FC4 indicator (availability of assistance) in Facilitating Conditions variable so that the indicator should be removed. The hypotheses show that Performance Expectancy, Hedonic Motivation, Habit, and Trust influence user's attitude to use BNI Mobile Banking. For Effort Expectancy, Social Influence, Facilitating Conditions, and Price Value, these variables do not influence user's attitude in using BNI Mobile Banking. For relation of Behavioral Intention, it influences use behavior of the user in using BNI Mobile Banking. As well as Use Behavior to Satisfaction, the result shows that Use Behavior influences user's Satisfaction in using BNI Mobile Banking. For moderator variables, Gender, Age, and Experience, it proves that it does not moderate Attitude to Behavioral Intention.

Based on analysis results, there is an impact related to performance on attitudes in using BNI Mobile Banking technology, service providers need to pay more attention to factors related to improving performance, service quality, effectiveness, and efficiency of the technology. Users can get the benefits they get in carrying out all their banking activities using this technology. In this regard, the benefits felt by users can increase the level of user enjoyment and can create 
conditions that can form a habit for users to use BNI Mobile Banking in carrying out all banking activities. Service providers also need to increase the level of user trust by increasing the security of the system.

\section{AUTHORS' CONTRIBUTIONS}

Rr. Putri Intan Paramaeswari: concepting the study, designing model, data collection, and paper writing. Riyanarto Sarno: supervising.

\section{ACKNOWLEDGEMENT}

This research was funded by the Indonesian Ministry of Education and Culture under Riset Inovatif-Produktif (RISPRO) Invitation Program managed by Lembaga Pengelola Dana Pendidikan (LPDP) and under Penelitian Terapan Unggulan Perguruan Tinggi (PTUPT) by Institut Teknologi Sepuluh Nopember (ITS).

\section{REFERENCES}

[1] V. Venkatesh, J. Y. L. Thong, and X. Xu, "Consumer Acceptance and Use of Information Technology: Extending the Unified Theory," vol. 36, no. 1, pp. 157-178, 2012.

[2] Hootsuite, "Indonesia Digital report 2020," Glob. Digit. Insights, p. 247, 2020, [Online]. Available:

https://datareportal.com/reports/digital-2020global-digital-overview.

[3] PT. BNI Tbk., "Laporan Tahunan BNI 2020 Satukan Energi untuk Kebangkitan Negeri," 2020. [Online]. Available: https://www.bni.co.id/id$\mathrm{id} /$ perusahaan/tatakelola/laporantatakelola/lapor antahunanpelaksanaantatakelola.

[4] R. P. I. Paramaeswari and R. Sarno, "Analysis of E-Commerce (Bukalapak, Shopee, and Tokopedia) acceptance models using TAM2 Method," Proc. - 2020 Int. Semin. Appl. Technol. Inf. Commun. IT Challenges Sustain. Scalability, Secur. Age Digit. Disruption, iSemantic 2020, pp. 505-510, 2020, doi: 10.1109/iSemantic50169.2020.9234271.

[5] D. Ridzky and R. Sarno, "UTAUT2 model for analyzing factors influencing user in using Online Travel Agent," Proc. - 2020 Int. Semin. Appl. Technol. Inf. Commun. IT Challenges Sustain. Scalability, Secur. Age Digit. Disruption, iSemantic 2020, vol. 2, no. Utaut 2, pp. 487-492, 2020, doi: 10.1109/iSemantic50169.2020.9234258.

[6] P. R. Maulidina, R. Sarno, K. R. Sungkono, and T. A. Giranita, "Using extended UTAUT2 Model to Determine Factors Influencing the Use of Shopee E-commerce," Proc. - 2020 Int. Semin. Appl. Technol. Inf. Commun. IT Challenges Sustain. Scalability, Secur. Age Digit. Disruption, iSemantic 2020, pp. 493-498, 2020, doi:

10.1109/iSemantic50169.2020.9234255.

[7] H. Dwinda and R. Sarno, "ANALYSING PUBLIC INTEREST IN SHARIA," Proc. 2020 Int. Semin. Appl. Technol. Inf. Commun. IT Challenges Sustain. Scalability, Secur. Age Digit. Disruption, iSemantic 2020, 2020, doi: 10.1109/iSemantic50169.2020.9234289.

[8] V. Venkatesh, M. G. Morris, G. B. Davis, and F. D. Davis, "User Acceptance of Information Technology Toward a Unified View," MIS $Q$., vol. 27, no. 3, pp. 425-478, 2003.

[9] W. W. Chin, "The partial least squares approach for structural equation modeling.," Mod. methods Bus. Res., no. January 1998, pp. 295336, 1998.

[10] M. Sarstedt, C. M. Ringle, and J. F. Hair, "Partial Least Squares Structural Equation Modeling," no. September, 2017, doi: 10.1007/978-3-319-05542-8.

[11] B. Eneizan, A. G. Mohammed, A. Alnoor, A. S. Alabboodi, and O. Enaizan, "Customer acceptance of mobile marketing in Jordan: An extended UTAUT2 model with trust and risk factors," Int. J. Eng. Bus. Manag., vol. 11, no. December, 2019, doi: 10.1177/1847979019889484.

[12] Z. Hussein, S. W. Oon, and A. Fikry, "Consumer Attitude: Does It Influencing the Intention to Use mHealth?," Procedia Comput. Sci., vol. 105, no. December 2016, pp. 340-344, 2016, doi: 10.1016/j.procs.2017.01.231.

[13] A. M. Baabdullah, A. A. Alalwan, N. P. Rana, H. Kizgin, and P. Patil, "Consumer use of mobile banking (M-Banking) in Saudi Arabia: Towards an integrated model," Int. J. Inf. Manage., vol. 44, no. September 2018, pp. 3852, 2019, doi: 10.1016/j.ijinfomgt.2018.09.002. 